\title{
Pengetahuan dan sikap suami berhubungan dengan perilaku keluarga mandiri sadar gizi (kadarzi) di Kota Bandung Provinsi Jawa Barat
}

\author{
Misbakhudin', Toto Sudargo², M. Dawam Jamil
}

\begin{abstract}
Background: A nutrition awareness of family (kadarzi) can be actualized through family empowerment by improving knowledge and attitude toward nutrition alert behavior. To implement the program of kadarzi needs a motivator, i.e. a husband as head of the family. The result of kadarzi mapping at Bandung Municipality in 2005 showed that $57.23 \%$ of families were not nutrition alert. Therefore, it is necessary to study the relationship between knowledge and attitude of husbands and behavior of kadarzi.

Objective: To identify the relationship between knowledge and attitude of husbands and behavior of kadarzi.

Method: The study was observational with cross sectional design using quantitative method. Analysed units were 378 households with husbands and wives as respondents. Location of the study was Bandung Municipality and samples were taken using multistage cluster technique. Data of knowledge and attitude of husbands in kadarzi were obtained through observation using check list. Data analysed with univariable and bivariable technique; statistical test used chi square $\left(\chi^{2}\right)$ and multivariable analysis used logistic regression statistical test.

Results: Knowledge of husbands on kadarzi was $63.2 \%$ belonged to high category and $36.6 \%$ belonged to low category. Attitude of husbands toward kadarzi was $53.2 \%$ belonged to strong category and $46.8 \%$ belonged to weak category. As much as $69.60 \%$ of families had not practiced kadarzi and $30.40 \%$ had practiced kadarzi. The result of statistical test showed that there were significant relationship between knowledge and attitude of husbands and behavior of kadarzi, wives' level of education and activities and behavior of kadarzi $(p<0.05)$.

Conclusion: There was a siginifcant relationship between knowledge and attitude of husbands and behavior of kadarzi when control variables of wives' education and activities were included in the analysis.
\end{abstract}

KEY WORDS behavior, kadarzi, knowledge, attitude, husbands

\section{PENDAHULUAN}

Program keluarga mandiri sadar gizi (kadarzi) merupakan upaya perbaikan gizi sebagai salah satu alternatif untuk menanggulangi masalah gizi. Visi pembangunan kesehatan yang ingin dicapai melalui pembangunan kesehatan yaitu Indonesia sehat 2010, ditetapkan bahwa $80 \%$ keluarga menjadi kadarzi, karena keluarga mempunyai nilai yang sangat strategis dan menjadi inti dalam pembangunan seluruh masyarakat, serta menjadi tumpuan dalam pembangunan manusia seutuhnya. Kadarzi adalah keluarga yang seluruh anggota keluarganya melakukan perilaku gizi seimbang, mampu mengenali masalah kesehatan dan gizi bagi setiap anggota keluarganya, dan mampu mengambil langkah-langkah untuk mengatasi masalah gizi yang dijumpai oleh anggota keluarganya (1).

Keadaan gizi masyarakat di Kota Bandung sampai saat ini belum memuaskan. Hasil pemetaan keluarga mandiri sadar gizi (kadarzi) tahun 2005 yaitu sebanyak 57,23\% keluarga belum kadarzi dan hanya sebanyak $42,77 \%$ keluarga yang sudah kadarzi (harapan $80 \%$ ) (2). Untuk mewujudkan kadarzi diperlukan setidaknya seorang motivator di dalam anggota keluarga yang memiliki pengetahuan dan sadar serta bersedia melakukan perubahan agar berperilaku gizi yang baik dan benar, di antaranya: ibu (istri), ayah (suami), anak, atau anggota keluarga lainnya (3).

Ayah atau suami sebagai kepala keluarga mempunyai peranan yang sangat menentukan di dalam keluarga. Suami berkewajiban memimpin dan membimbing keluarga, melindungi istri dan anak, memberikan nafkah lahir dan batin, mengatasi keadaan dan mencari penyelesaian secara bijaksana, serta tidak bertindak sewenang-wenang, dan mau membantu tugas istri dalam mengatur urusan rumah tangga (4). Oleh karena itu, perlu dilakukan penelitian tentang pengetahuan dan sikap suami tentang indikator kadarzi serta hubungannya dengan perilaku kadarzi. Tujuan penelitian ini adalah untuk mengetahui hubungan antara pengetahuan dan sikap suami tentang indikator kadarzi dengan perilaku kadarzi.

\footnotetext{
Dinas Kesehatan Kota Bandung, Jl. Supratman 73, Bandung, Jawa Barat

2 Magister Gizi dan Kesehatan UGM, JI Farmako, Sekip Utara, Yogyakarta 55281, e-mail: totosud@indosat.net.id

3 Jurusan Gizi Politeknik Kesehatan Departemen Kesehatan RI, JI. Tatabumi No. 3 Yogyakarta, e-mail: dawam_j@yahoo.com
} 


\section{BAHAN DAN METODE}

Jenis penelitian ini adalah observasional dengan rancangan cross sectional. Metode penelitian dengan pendekatan kuantitatif. Penelitian ini dilakukan untuk mengetahui hubungan antara variabel bebas dengan variabel terikat dan variabel pengganggu yang dikendalikan. Variabel bebas adalah pengetahuan dan sikap suami tentang indikator kadarzi, variabel terikat adalah perilaku kadarzi, serta variabel pengganggu adalah pendidikan suami, pekerjaan suami, pendapatan suami, pendidikan istri dan aktivitas istri. Pengumpulan data dilakukan pada waktu yang bersamaan.

Penelitian ini dilakukan pada bulan November 2006 sampai dengan Januari 2007 di Kota Bandung Provinsi Jawa Barat. Unit analisis penelitian ini adalah rumah tangga dengan responden penelitian adalah suami beserta istri. Teknik pengambilan sampel dilakukan secara cluster (gugus) bertahap. Jumlah unit analisis dihitung menggunakan rumus besaran sampel menurut Lemeshow et al. (5) dengan tingkat kepercayaan 95\%, perkiraan proporsi pemetaan kadarzi sebesar 0,43 , dan persentase kemungkinan kesalahan sebesar 0,05.

Berdasarkan rumus tersebut, diperoleh jumlah unit analisis minimal adalah 377 rumah tangga yang memenuhi kriteria inklusi, antara lain: bertempat tinggal di wilayah Kota Bandung, mempunyai balita berusia $\geq 6-36$ bulan, tinggal bersama anak dan istri, serta suami dan istri bersedia menjadi responden.

Instrumen atau alat penelitian yang digunakan adalah kuesioner atau daftar pertanyaan terstruktur untuk mengumpulkan data pengetahuan dan sikap suami tentang kadarzi. Check list observasi digunakan untuk mengumpulkan data perilaku kadarzi. Secara kerseluruhan, keluarga responden dikatakan berperilaku kadarzi apabila sudah melaksanakan ke lima indikator kadarzi, yaitu : mengkonsumsi beraneka ragam makanan, memantau status gizi, menggunakan garam beriodium, memberikan ASI eksklusif, dan membiasakan sarapan pagi. Apabila salah satu belum dipenuhi, maka dikatakan belum berperilaku kadarzi.

Analisis data dilakukan dengan analisis univariat, bivariat, dan multivariat. Pengujian statististik dilakukan dengan menggunakan uji kai-kuadrat $\left({ }^{2}\right)$ atau chi square dan uji regresi logistik dengan tingkat kepercayaan $95 \%$.

\section{HASIL DAN BAHASAN}

\section{Karakteristik responden}

Karakteristik responden yang ingin diketahui meliputi pendidikan responden, pekerjaan dan pendapatan suami, serta aktivitas istri. Distribusi pendidikan responden dapat dilihat pada Tabel 1. Berdasarkan tabel tersebut, tingkat pendidikan responden sebagian besar sekolah menengah atas (SMA). Suami yang berpendidikan SMA sebesar $48,7 \%$ dan istri sebesar $45,8 \%$, sehingga sebagian besar responden telah menempuh wajib belajar 9 tahun. Dengan tingkat pendidikan yang lebih tinggi tersebut, diharapkan responden dapat lebih mudah menerima informasi-informasi gizi dan kesehatan untuk dipraktikkan dalam kehidupan sehari-hari.

Pekerjaan suami paling banyak adalah pegawai swasta yaitu sebesar $33,9 \%$, namun sebesar $7,9 \%$ suami tidak mempunyai pekerjaan.

Berdasarkan Surat Keputusan Gubernur Jawa Barat nomor 561/Kep.1142-Bangsos/2006, upah minimum di Kota Bandung sebesar Rp 860.565,00. Standar upah minimum tersebut diharapkan dapat memenuhi kebutuhan hidup minimum seorang pegawai dengan layak. Hasil survei menunjukkan bahwa median pendapatan responden adalah Rp 1.000.000,00.

Dari Tabel 1 juga diketahui bahwa sebagian besar istri $(85,2 \%)$ beraktivitas sebagai ibu rumah tangga dan hanya sebagian kecil $(14,8 \%)$ yang bekerja. Untuk memenuhi kebutuhan keluarga, sebagian besar istri bergantung pada pendapatan suami. Distribusi pendapatan suami per bulan dan aktivitas istri dapat dilihat pada Tabel 1.

\section{Pengetahuan suami tentang indikator kadarzi}

Untuk menilai pengetahuan suami tentang indikator kadarzi, suami diberikan 29 pertanyaan. Skor nilai minimum adalah 0 dan maksimum adalah 29. Hasil penilaian pengetahuan suami tersebut dapat dilihat pada Tabel 1. Berdasarkan tabel tersebut, diketahui tingkatan pengetahuan suami tentang indikator kadarzi. Dari 378 responden tersebut, sebanyak $63,2 \%$ pengetahuan suami termasuk dalam kategori tinggi dan sebanyak $36,6 \%$ yang termasuk dalam kategori rendah. Hasil analisis juga diketahui skor nilai pengetahuan yang terendah adalah 7 dan yang tertinggi adalah 29 dengan rata-rata skor nilai adalah 22,74.

\section{Sikap suami tentang indikator kadarzi}

Untuk menilai sikap suami tentang indikator kadarzi, disiapkan daftar pertanyaan sejumlah 30 soal. Skor nilai sikap tentang indikator kadarzi yang minimal adalah 0 dan maksimal adalah 90 yang hasilnya dapat dilihat pada Tabel 1. Suami yang bersikap kuat untuk mempraktikkan indikator kadarzi adalah sebesar $53,2 \%$ dan yang bersikap lemah sebesar $46,8 \%$. Skor nilai sikap yang terlemah adalah 42 dan yang terkuat adalah 87 dengan rata-rata skor nilai sebesar 65,31 . 


\section{Perilaku kadarzi}

Perilaku kadarzi adalah kebiasaan keluarga melaksanakan kelima indikator kadarzi, yang meliputi: mengkonsumsi beraneka ragam makanan, memantau status gizi, menggunakan garam beryodium, memberikan ASI eksklusif, dan sarapan atau makan pagi. Hasil observasi perilaku kadarzi terhadap 378 keluarga/rumah tangga dapat dilihat pada Tabel 1. Dari hasil tersebut, diketahui sebanyak 115 keluarga $(30,40 \%)$ yang sudah menerapkan perilaku kadarzi dan 263 keluarga $(69,60 \%)$ yang belum menerapkan perilaku kadarzi.

Adapun pelaksanaan masing-masing indikator kadarzi dapat dilihat pada Tabel 2. Indikator kadarzi yang paling banyak belum dipraktikkan dalam kehidupan sehari-hari adalah kebiasaan keluarga dalam memberikan ASI eksklusif yaitu sebanyak $60,60 \%$. Sebaliknya, indikator kadarzi yang sudah banyak dipraktikkan adalah sarapan/ makan pagi yaitu sebanyak $96,00 \%$, menggunakan garam beryodium sebanyak $95,50 \%$, kebiasaan keluarga mengkonsumsi beraneka ragam makanan sebanyak $94,20 \%$, dan yang memantau status gizi sebanyak $81,00 \%$

\section{Hubungan pengetahuan suami tentang indikator kadarzi dengan perilaku kadarzi}

Di antara suami yang mempunyai pengetahuan tinggi tentang indikator kadarzi, hanya 102 orang $(42,7 \%)$ yang sudah berperilaku kadarzi, namun 137 orang sisanya $(57,3 \%)$ dinilai belum berperilaku kadarzi (Tabel 3 ). Berdasarkan uji kai-kuadrat untuk mengetahui hubungan antara pengetahuan suami tentang indikator gizi dengan perilaku gizi didapatkan nilai $p<0,001$, yang menunjukkan ada perbedaan proporsi pengetahuan suami tentang indikator kadarzi yang signifikan antara suami berpengetahuan rendah dan tinggi dengan perilaku kadarzi. Nilai $\mathrm{OR}=7,2$ menunjukkan bahwa suami yang mempunyai pengetahuan rendah memiliki peluang berperilaku kadarzi 7,2 kali lebih kecil dibanding dengan suami yang mempunyai pengetahuan tinggi.

Hasil penelitian ini sejalan dengan penelitian Gunanti (6) mengenai pola pemberian ASI, MP-ASI, dan status gizi anak usia 1-2 tahun. Pengetahuan gizi ibu menentukan segala sesuatu yang dimakan oleh anak karena pengetahuan mempengaruhi perilaku pemilihan makanan. Departemen Kesehatan RI (7) mengembangkan teori bahwa 
TABEL 2. Distribusi pelaksanaan indikator kadarzi

\begin{tabular}{lcccccc}
\hline \multirow{2}{*}{\multicolumn{1}{c}{ Indikator kadarzi }} & \multicolumn{3}{c}{ Pelaksanaan indikator kadarzi } & \multicolumn{2}{c}{ Jumlah } \\
\cline { 2 - 5 } & \multicolumn{2}{c}{ Belum } & $\mathbf{n}$ Sudah & & $\mathbf{n}$ \\
\cline { 2 - 6 } & $\mathbf{n}$ & $\mathbf{\%}$ & $\mathbf{n}$ & $\mathbf{\%}$ & $\mathbf{n}$ & $\mathbf{\%}$ \\
\hline Konsumsi beraneka ragam makanan & 22 & 5,80 & 356 & 94,20 & 378 & 100 \\
Memantau status gizi & 72 & 19,00 & 306 & 81,00 & 378 & 100 \\
Menggunakan garam beryodium & 17 & 4,5 & 361 & 95,50 & 378 & 100 \\
ASI eksklusif & 229 & 60,60 & 149 & 39,40 & 378 & 100 \\
Sarapan/makan pagi & 15 & 4,00 & 363 & 96,00 & 378 & 100 \\
\hline
\end{tabular}

TABEL 3. Hubungan pengetahuan suami tentang indikator kadarzi dengan perilaku kadarzi

\begin{tabular}{lccccc}
\hline \multirow{2}{*}{ Pengetahuan suami } & \multicolumn{2}{c}{ Kadari } & \multirow{2}{*}{ P } & \multirow{2}{*}{ OR } & \multirow{2}{*}{ IK 95\% } \\
\cline { 2 - 3 } Rendah (< rata-rata) & Belum & Sudah & & 13 \\
& 126 & & & \\
Tinggi ( $\geq$ rata-rata) & $(90,6 \%)$ & $(9,4 \%)$ & $0,000^{*}$ & 7,2 & $3,86-13,49$ \\
& 137 & 102 & & & \\
\hline
\end{tabular}

Keterangan:

* Signifikan $(p<0,05)$

tingkat pengetahuan akan sangat berpengaruh terhadap kesadaran untuk berperan serta dan mempunyai dampak terhadap perilaku, sehingga dengan pengetahuan suami tentang indikator kadarzi yang makin tinggi akan berdampak terhadap perilaku kadarzi.

Notoatmodjo (8) menyampaikan perubahan atau penerimaan atau pengadopsian perilaku baru dalam kehidupan seseorang melalui tiga tahap. Tahapan pertama adalah adanya pengetahuan. Sebelum seseorang berperilaku atau mengadopsi perilaku, orang tersebut harus tahu terlebih dahulu arti atau manfaat sesuatu hal bagi diri atau keluarganya. Orang akan melakukan kadarzi apabila orang tersebut tahu tujuan dan manfaat bagi kesehatan beserta risikonya apabila tidak melakukan kadarzi. Tahapan kedua adalah bersikap. Seseorang yang telah mengetahui kadarzi atau sesuatu objek yang diperoleh dari pengalaman, orang tua, guru, teman, bukubuku, dan media-media informasi lain akan mengadakan penilaian yang selanjutnya dipersepsikan dalam sikap. Pada tahapan ketiga diharapkan seseorang akan melaksanakan atau berperilaku sesuai dengan segala sesuatu yang diketahuinya.
Hubungan pengetahuan suami dengan masing-masing indikator perilaku kadarzi dapat dijelaskan pada Tabel 4. Berdasarkan tabel tersebut diketahui bahwa di antara 5 indikator kadarzi hanya 3 indikator yang memiliki hubungan bermakna dengan pengetahuan suami, yaitu indikator kebiasaan memantau status gizi, menggunakan garam beryodium, dan ASI eksklusif. Upaya-upaya yang ditekankan untuk meningkatkan pengetahuan suami tentang indikator kadarzi antara lain: menggunakan garam beryodium, ASI eksklusif, dan memantau status gizi.

\section{Hubungan sikap suami tentang indikator kadarzi dengan perilaku kadarzi}

Di antara suami yang sikap kadarzinya dikategorikan kuat, sebagian besar yaitu 102 orang $(50,7 \%)$ dinilai sudah berperilaku kadarzi baik, sedangkan 99 orang sisanya $(49,3 \%$ ) belum berperilaku kadarzi baik (Tabel 5 ).

Berdasarkan uji kai-kuadrat untuk mengetahui hubungan antara sikap suami tentang indikator gizi dengan perilaku kadarzi diperoleh nilai $p<0,001$ yang menunjukkan ada perbedaan proporsi yang bermakna antara sikap suami lemah dan kuat dengan kadarzi. Nilai

TABEL 4. Hubungan pengetahuan suami dengan masing-masing indikator perilaku kadarzi

\begin{tabular}{lccc}
\hline \multicolumn{1}{c}{ Hubungan indikator kadarzi } & $\mathbf{p}$ & OR & IK 95\% \\
\hline Konsumsi beraneka ragam makanan & 0,075 & 2,16 & $0,91-5,15$ \\
Memantau status gizi & $0,001^{*}$ & 2,44 & $1,45-4,10$ \\
Menggunakan garam beryodium & $0,001^{*}$ & 6,06 & $1,94-18,98$ \\
ASI eksklusif & $0,000^{*}$ & 3,21 & $2,01-5,13$ \\
Sarapan/makan pagi & 0,057 & 2,69 & $0,94-7,72$ \\
\hline
\end{tabular}

Keterangan:

* Signifikan $(p<0,05)$ 
TABEL 5. Hubungan sikap suami tentang indikator kadarzi dengan perilaku kadarzi

\begin{tabular}{lccccc}
\hline \multirow{2}{*}{ Sikap suami } & \multicolumn{2}{c}{ Kadarzi } & \multirow{2}{*}{ P } & \multirow{2}{*}{ OR } & \multirow{2}{*}{ IK 95\% } \\
\cline { 2 - 3 } & Belum & Sudah & & 13 \\
Lemah (< rata-rata) & 164 & \multirow{2}{*}{0,000} & \multirow{2}{*}{13} & \multirow{2}{*}{$6,93-24,38$} \\
Kuat ( $\geq$ rata-rata) & $(92,7 \%)$ & $(7,3 \%)$ & & & \\
& 99 & 102 & & & \\
\hline
\end{tabular}

Keterangan:

* Signifikan $(p<0,05)$

TABEL 6. Hubungan pengetahuan suami tentang indikator kadarzi dengan sikap suami tentang indikator kadarzi

\begin{tabular}{|c|c|c|c|c|c|}
\hline \multirow{2}{*}{ Pengetahuan suami } & \multicolumn{2}{|c|}{ Sikap suami } & \multirow[b]{2}{*}{$\mathbf{p}$} & \multirow{2}{*}{ OR } & \multirow{2}{*}{ IK 95\% } \\
\hline & Lemah & Kuat & & & \\
\hline Rendah (< rata-rata) & $\begin{array}{c}105 \\
(75,5 \%)\end{array}$ & $\begin{array}{c}34 \\
(24,5 \%)\end{array}$ & $0,000^{*}$ & 7,16 & $4,45-11,52$ \\
\hline Tinggi ( $\geq$ rata-rata) & $\begin{array}{c}72 \\
(30,1 \%) \\
\end{array}$ & $\begin{array}{c}167 \\
(69,9 \%) \\
\end{array}$ & & & \\
\hline
\end{tabular}

Keterangan:

* Signifikan $(p<0,05)$

OR=13 menunjukkan suami yang mempunyai sikap lemah tentang indikator gizi akan memiliki peluang berperilaku kadarzi 13 kali lebih rendah dibanding dengan suami yang mempunyai sikap kuat.

Tahapan perubahan perilaku yang pertama adalah adanya pengetahuan yang kemudian dipersepsikan dalam sikap. Hubungan pengetahuan suami tentang indikator kadarzi dengan sikap suami tentang indikator kadarzi dijelaskan pada Tabel 6. Berdasarkan tabel tersebut diketahui bahwa hubungan antara pengetahuan suami tentang indikator kadarzi dengan sikap suami tentang indikator kadarzi mempunyai hubungan yang bermakna $(p<0,05)$. Suami yang telah mengetahui dan paham tentang indikator kadarzi akan bersikap sesuai dengan yang diketahuinya dan proses selanjutnya diharap terjadinya perilaku kadarzi.

Sikap juga merupakan salah satu faktor predisposisi terjadinya perilaku, sehingga sikap suami tentang indikator kadarzi yang kuat akan menentukan terjadinya perilaku kadarzi. Newcomb cit. Notoatmodjo (9) berpendapat bahwa sikap merupakan kesiapan atau kesediaan untuk bertindak/ berperilaku. Oleh karena itu, sikap suami yang kuat terhadap kadarzi akan memberikan kesiapan atau kesediaan yang lebih baik untuk melaksanakan kadarzi. Selain itu, suami sebagai kepala keluarga berkewajiban memimpin dan membimbing keluarga untuk memotivasi terwujudnya perilaku kadarzi. Penelitian Widodo et al. (10) membuktikan bahwa sikap yang baik dapat mendorong perilaku yang baik pula, sikap yang negatif terhadap kehamilan serta persepsi yang kurang baik terhadap pemeriksaan kehamilan merupakan faktor penghalang antenatal care (pemeriksaan kehamilan).

Hubungan sikap suami dengan masing-masing indikator perilaku kadarzi dapat dilihat pada Tabel 7. Hubungan sikap suami dengan masing-masing indikator perilaku kadarzi menunjukkan hubungan yang bermakna $(p<0,05)$. Upayaupaya dalam meningkatkan sikap suami terhadap kadarzi hendaknya menitikberatkan pada materi garam beryodium, sarapan/makan pagi, ASI eksklusif, memantau status gizi dan konsumsi beraneka ragam makanan.

Hubungan pendidikan suami, pekerjaan suami, pendapatan suami, pendidikan istri, dan aktivitas istri dengan perilaku kadarzi

Variabel pendidikan suami, pekerjaan suami, pendapatan suami, pendidikan istri, dan aktivitas istri dalam

TABEL 7. Hubungan sikap suami dengan masing-masing indikator perilaku kadarzi

\begin{tabular}{lccc}
\hline \multicolumn{1}{c}{ Hubungan indikator kadarzi } & p & OR & IK 95\% \\
\hline Konsumsi beraneka ragam makanan & $0,039^{*}$ & 2,57 & $1,02-6,45$ \\
Memantau status gizi & $0,000^{*}$ & 2,96 & $1,72-5,11$ \\
Menggunakan garam beryodium & $0,003^{*}$ & 5,67 & $1,60-20,07$ \\
ASI eksklusif & $0,000^{*}$ & 3,85 & $2,47-6,02$ \\
Sarapan/makan pagi & $0,009^{*}$ & 4,80 & $1,33-17,30$ \\
\hline
\end{tabular}

Keterangan:

* Signifikan $(p<0,05)$ 
TABEL 8. Hubungan pendidikan suami, pekerjaan suami, pendapatan suami, pendidikan istri, dan aktivitas istri dengan perilaku kadarzi

\begin{tabular}{lccc}
\hline \multicolumn{1}{c}{ Variabel } & p & OR & IK 95\% \\
\hline Pendidikan Suami & $0,000^{*}$ & 2,34 & $1,47-3,72$ \\
Pekerjaan Suami & $0,024^{*}$ & 1,67 & $1,07-2,61$ \\
Pendapatan Suami & $0,000^{*}$ & 2,94 & $1,78-4,86$ \\
Pendidikan Istri & $0,000^{*}$ & 2,55 & $1,61-4,02$ \\
Aktivitas Istri & $0,000^{*}$ & 0,15 & $0,05-0,42$ \\
\hline
\end{tabular}

Keterangan:

* Signifikan $(p<0,05)$

TABEL 9. Variabel kandidat determinan hubungan perilaku kadarzi

\begin{tabular}{lccc}
\hline \multicolumn{1}{c}{ Variabel } & -2 log likelihood & Kai-kuadrat & p \\
\hline Pengetahuan suami & 416,163 & 48,330 & 0,000 \\
Sikap suami & 341,339 & 123,153 & 0,000 \\
Pendidikan suami & 451,047 & 13,446 & 0,000 \\
Pekerjaan suami & 459,439 & 5,053 & 0,024 \\
Pendapatan suami & 446,801 & 17,691 & 0,000 \\
Pendidikan istri & 447,713 & 16,780 & 0,000 \\
Aktivitas istri & 443,631 & 20,862 & 0,000 \\
\hline
\end{tabular}

penelitian ini merupakan variabel pengganggu. Hubungan variabel-variabel tersebut dengan perilaku kadarzi dijelaskan pada Tabel 8. Dari tabel tersebut diketahui adanya hubungan bermakna antara masing-masing variabel pendidikan suami, pekerjaan suami, pendapatan suami, pendidikan istri, dan aktivitas istri dengan perilaku kadarzi $(p<0,05)$. Variabel-variabel tersebut mempunyai kontribusi terhadap perilaku kadarzi sehingga akan mendistorsi hubungan pengetahuan suami dan sikap suami dengan perilaku kadarzi. Oleh karena itu, variabel-variabel tersebut akan dianalisis secara multivariat dengan pengujian statistik regresi logistik.

\section{Variabel determinan hubungan perilaku kadarzi}

Untuk mengetahui variabel yang berhubungan dengan perilaku kadarzi, dilakukan analisis multivariat. Variabel yang dimasukkan dalam analisis multivariat adalah variabel yang memiliki nilai $p<0,25$ hasil analisis bivariat (11). Variabel yang diduga berhubungan dengan perilaku kadarzi antara lain: variabel pengetahuan suami, sikap suami, pendidikan suami, pekerjaan suami, pendapatan suami, pendidikan istri, dan aktivitas istri. Hasil analisis bivariat variabel-variabel tersebut dijelaskan pada Tabel 9.

\section{Hasil model pengujian variabel-variabel determinan} perilaku kadarzi

Hasil model pengujian variabel-variabel determinan perilaku kadarzi dijelaskan pada Tabel 10. Dari tabel tersebut diketahui bahwa signifikansi log likelihood $(p=0,000)$ kurang dari 0,01 dan signifikansi $p$ Wald yaitu: variabel pengetahuan suami, sikap suami, pendidikan istri, dan aktivitas istri nilainya kurang dari 0,05 . Hal ini berarti ada berhubungan yang signifikan $(p<0,05)$ antara pengetahuan suami tentang indikator kadarzi, sikap suami tentang indikator kadarzi, pendidikan istri, dan aktivitas istri dengan perilaku kadarzi.

Nilai $O R=3,26$ untuk variabel pengetahuan suami memberi arti suami yang berpengetahuan tinggi tentang

TABEL 10. Hasil analisis variabel determinan perilaku kadarzi (variabel pengetahuan suami, sikap suami, pendidikan istri, dan aktivitas istri)

\begin{tabular}{lcccc}
\hline \multicolumn{1}{c}{ Variabel } & B & p Wald & OR & IK 95\% \\
\hline Pengetahuan suami & 1,18 & $0,001^{*}$ & 3,26 & $1,60-6,62$ \\
Sikap suami & 2,31 & $0,000^{*}$ & 10,08 & $5,16-19,68$ \\
Pendidikan istri & 0,74 & $0,009^{*}$ & 2,10 & $1,21-3,64$ \\
Aktivitas istri & $-2,32$ & $0,000^{*}$ & 0,10 & $0,03-0,30$ \\
Konstanta & $-5,34$ & 0,000 & 0,01 & - \\
\hline
\end{tabular}

Keterangan:

$-2 \log$ likelihood $=325,821$ Kai-kuadrat $=138,672 p=0,000$ 
TABEL 11. Hasil uji interaksi

\begin{tabular}{|c|c|c|c|}
\hline Interaksi & -2 log likelihood & Kai-kuadrat & $\mathbf{p}$ \\
\hline Pengetahuan suami*sikap suami & 325,821 & 138,672 & 0,000 \\
\hline Pengetahuan suami*pendidikan istri & 325,732 & 4,486 & $0,034^{*}$ \\
\hline Pengetahaun suami*aktivitas istri & 325,821 & 138,672 & $0,000^{*}$ \\
\hline Sikap suami*pendidikan istri & 325,821 & 138,672 & $0,000^{*}$ \\
\hline Sikap suami*aktivitas istri & 325,821 & 138,672 & $0,000^{*}$ \\
\hline Pendidikan istri*aktivitas istri & 325,821 & 138,672 & $0,000^{*}$ \\
\hline Pengetahuan*sikap*aktivitas ${ }^{*}$ pendidikan & 325,821 & 138,672 & $0,000^{*}$ \\
\hline
\end{tabular}

Keterangan:

* Signifikan $(p<0,05)$

indikator kadarzi memiliki peluang berperilaku kadarzi 3,26 kali (IK 95\%:1,60-6,62) lebih besar dibanding yang berpengetahuan rendah, setelah dikendalikan oleh variabel sikap suami, pendidikan istri, dan aktivitas istri. Nilai $\mathrm{OR}=10,08$ untuk variabel sikap suami memberi arti sikap suami tentang indikator kadarzi yang kuat berpeluang mempunyai perilaku kadarzi 10,08 kali (IK 95\%:5,16-19,68) lebih besar dibanding sikap suami tentang indikator kadarzi yang rendah, setelah dikendalikan variabel pengetahuan suami, pendidikan istri, dan aktivitas istri. Nilai $\mathrm{OR}=0,10$ untuk variabel aktivitas istri yang berarti istri yang bekerja mempunyai risiko tidak berperilaku kadarzi 0,10 kali (IK 95\%: 0,030,30 ) lebih besar dibanding yang tidak bekerja. Hal ini mungkin disebabkan kesibukan bekerja sehingga istri kurang dapat memperhatikan gizi dan kesehatan keluarganya. Selain itu, istri yang bekerja tidak dapat memberikan ASI secara eksklusif selama 6 bulan. Hal ini sesuai dengan hasil analisis bahwa indikator kadarzi yang paling banyak belum dilaksanakan adalah ASI eksklusif yaitu sebesar $60,60 \%$. Soeparmanto dan Pranata (12) juga melakukan penelitian mengenai faktorfaktor yang mempengaruhi pemberian ASI eksklusif pada bayi. Hasilnya menunjukkan bahwa pola menyusui eksklusif selama 4 bulan pada ibu yang bekerja lebih rendah daripada ibu yang tidak bekerja dan di daerah perkotaan lebih rendah dibanding di daerah pedesaan.

Variabel pengetahuan suami tentang kadarzi, sikap suami tentang kadarzi, pendidikan istri, dan aktivitas istri saling berinteraksi dan saling menunjang untuk terjadinya perilaku kadarzi. Hasil uji interaksi tersebut dapat dilihat pada Tabel 11.

Green (13) mengatakan bahwa perilaku manusia di bidang kesehatan dipengaruhi oleh dua faktor, yaitu faktor perilaku dan faktor nonperilaku. Perilaku itu sendiri dipengaruhi oleh tiga faktor, antara lain: faktor predisposisi (pengetahuan, sikap, kebiasaan, kepercayaan, keyakinan, nilai-nilai sosial, dan elemen-elemen lain), faktor pemungkin (adanya fasilitas dan sarana-sarana lain), dan faktor penguat (pengaruh orang penting, peraturan- peraturan, struktur sosial, dan lain-lain). Faktor-faktor tesebut saling menentukan dan saling berhubungan dalam pembentukan perilaku seseorang atau kelompok, dalam hal ini adalah kadarzi.

Di samping pengetahuan dan sikap suami, pendidikan istri juga turut menentukan terjadinya perilaku kadarzi. Menurut Sarwono (14), seseorang yang memiliki tingkat pendidikan rendah relatif sulit menerima sesuatu hal yang baru, sebaliknya seseorang yang memiliki pendidikan tinggi akan lebih mudah menerima hal baru dan cenderung lebih terbuka. Pengetahuan suami tentang kadarzi yang tinggi dan sikap suami tentang kadarzi yang kuat akan menjadi motivator terjadinya perilaku kadarzi di dalam keluarga, didukung oleh pendidikan istri dan aktivitas istri.

\section{KESIMPULAN DAN SARAN}

\section{Kesimpulan}

Ada hubungan antara pengetahuan suami tentang indikator kadarzi dengan perilaku kadarzi, setelah dikendalikan sikap suami, pendidikan istri, dan aktivitas istri.

Selain itu, ada pula hubungan antara sikap suami tentang indikator kadarzi dengan perilaku kadarzi setelah dikendalikan pengetahuan suami, pendidikan istri dan aktivitas istri.

\section{Saran}

Dinas kesehatan atau pembuat kebijakan perlu menyusun program-program peningkatan pemberian ASI eksklusif selama 6 bulan untuk meningkatkan perilaku kadarzi. Perlu pula dilakukan pemasaran atau promosi kadarzi melalui media massa baik cetak (surat kabar, majalah) maupun elektronik (radio, TV) yang banyak dimanfaatkan oleh para suami.

Bagi peneliti lain juga diharapkan dapat meneliti faktorfaktor lain yang berhubungan dengan perilaku kadarzi, seperti: faktor kebiasaan, kepercayaan, peraturan-peraturan, sarana, fasilitas, dan lain-lain. 


\section{RUJUKAN}

1. Departemen Kesehatan RI. Panduan Umum Keluarga Mandiri Sadar Gizi (Kadarzi). Jakarta: Departemen Kesehatan RI; 2002.

2. Dinas Kesehatan Kota Bandung. Laporan Tahunan 2005 Seksi Gizi Dinas Kesehatan Kota Bandung. Bandung: Dinas Kesehatan; 2005.

3. Departemen Kesehatan RI. Pedoman Pemetaan Keluarga Mandiri Sadar Gizi. Jakarta: Departemen Kesehatan RI; 2000.

4. Departemen Agama RI. Buku Nikah. Jakarta: Departemen Agama RI; 1998.

5. Lemeshow S, Hosmer D, Klar J. 1990. Adequacy of Sample Size in Health Studies. (Terjemahan) Pramono D. Yogyakarta: UGM Press; 1997. h. 49-52.

6. Gunanti RI, Devi RS, Adriani M. Pemberdayaan Kader Posyandu melalui Penerapan Metode Konseling Gizi dalam Upaya Meningkatkan Kualitas Pembinaan Program Keluarga Mandiri Sadar Gizi (Kadarzi). Jurnal Buletin Penelitian Sistem Kesehatan 2005;8:47-58.

7. Departemen Kesehatan RI. Peningkatan Peran Serta Masyarakat dalam Kegiatan Posyandu. Jakarta: Departemen Kesehatan Rl;1996.
8. Notoatmodjo S. Pendidikan dan Perilaku Kesehatan. Jakarta: Rineka Cipta; 2003.

9. Notoatmodjo S. Promosi Kesehatan Teori dan Aplikasinya. Jakarta: Rineka Cipta; 2005.

10. Widodo AD, Anggarani AM, Halim A, Maureen A, Landy $B$, Suarthana E, et al. Pengetahuan, Sikap, dan Perilaku tentang Kehamilan, Persalinan serta Komplikasinya pada Ibu Hamil Nonprimigravida di RSUPN Cipto Mangunkusumo. Majalah Kedokteran Indonesia 2005;55(10):25-8.

11. Murti B. Prinsip dan Metode Riset Epidemiologi. Yogyakarta: Gadjah Mada University Press;1997.

12. Soeparmanto P, Pranata S. Faktor-Faktor yang Mempengaruhi Pemberian Air Susu lbu (ASI) Eksklusif pada Bayi. Jurnal Buletin Penelitian Sistem Kesehatan 2005;8:1-7.

13. Green LW. Health Promotion Planning an Education and Enviromental Approach. 2nd ed. Toronto London: Mayfield Publishing Company; 1991.

14. Sarwono S. Sosiologi Kesehatan, Beberapa Konsep Beserta Aplikasinya. Yogyakarta: Gadjah Mada University Press; 2004. 